J. Lake Sci. (湖泊科学), 2015, 27(2): 275-281

http : //www. jlakes.org. E-mail : jlakes@niglas.ac.cn

(c) 2015 by Journal of Lake Sciences

\title{
江西柘林湖富营养化现状与藻类时空分布特征
}

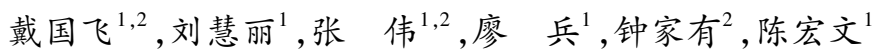 \\ ( 1 : 江西省环境保护科学研究院, 南昌 330039$)$ \\ ( 2 : 江西省水利科学研究院鄱阳湖水资源与环境重点实验室,南昌 330029)
}

摘 要: 江西柘林湖是首批入围国家良好湖泊保护专项的示范湖泊. 为揭示柘林湖富营养化现状与藻类时空演替特征, 于 2012 年 8 月至 2013 年 7 月对全湖及主要人湖支流进行了周年采样分析,结果表明:柘林湖主要营养盐在地表水 III 类 以内, 处于中营养状态. 全湖藻类演替以蓝藻-硅藻交替为主, 夏季以鱼腥藻和微囊藻为优势种, 冬季直链藻、小环藻和针 杆藻占优. 藻类空间分布呈现西部高于东部、上游高于下游的特征, 西部部分湖区夏季甚至出现了鱼腥藻水华. 柘林湖 3 个大型饮用水源地中东渡水源地夏季也同样面临蓝藻水华问题,但蓝藻毒素未超标. 在重点监测的 4 条柘林湖主要人湖 支流中, 3 条支流的藻类夏、冬季细胞丰度均在 $1 \times 10^{7} \mathrm{cells} / \mathrm{L}$ 以下,但烟港水的藻细胞丰度夏、冬季分别接近和超过该界 限, 应加以警惕并采取适当措施. 枯水期水位变化、水体分层、较低的水体透明度和较长的滞留时间是影响柘林湖局部湖 区蓝藻水华形成的关键因素.

关键词: 良好湖泊;柘林湖;藻类演替;蓝藻水华;生态安全;饮用水安全

\section{Spatio-temporal variation of algae and eutrophic status of Lake Zhelin, Jiangxi Province}

\author{
DAI Guofei ${ }^{1,2}$, LIU Huili ${ }^{1}$, ZHANG Wei ${ }^{1,2}$, LIAO Bing ${ }^{1}$, ZHONG Jiayou ${ }^{2} \&$ CHEN Hongwen ${ }^{1}$ \\ (1: Jiangxi Academy of Environmental Science, Nanchang 330039, P. R. China) \\ (2: Jiangxi Provincial Key Laboratory of Water Resources and Environment of Poyang Lake, Jiangxi Institute of Water Sci- \\ ences, Nanchang 330029 , P. R. China)
}

\begin{abstract}
Lake Zhelin in Jiangxi Province is among the first batch of demonstrative lakes in the "High Quality and Healthy Lake Plan” initiated by Chinese government. To study its spatio-temporal variation of algae and water eutrophication status, sampling sites in both Lake Zhelin and rivers flow into it were investigated from August 2012 to July 2013. The results showed that Lake Zhelin belongs to mesotrophic waters, with average total nitrogen and phosphorus concentration $<1 \mathrm{mg} / \mathrm{L}$ and $<0.05 \mathrm{mg} / \mathrm{L}$, respectively. The development of algae in Lake Zhelin mainly shifted between cyanobacteria(Microcystis and Anabaena) in the summer and diatom(Melosira, Cyllotella and Synedra) in the winter. Cyanobacteria bloom happened in the west of the lake, with a much higher abundance than that in the east. There are three main drinking water sources in Lake Zhelin and one of them suffered from cyanobacterial bloom during summer. However, microcystin concentration in the drinking water was still far below the safety guideline $1 \mu \mathrm{g} / \mathrm{L}$. The algae cell abundance in the three main rivers into Lake Zhelin was still low, and the algae cell abundance in Yangang River was near $1 \times 10^{7}$ cells/L in both summer and winter. The decrease of input water volume and water level in Lake Zhelin in dry seasons, stratification of the water column, low water transparency together with long retention time of the lake water were the main causes of the blooms in Lake Zhelin.
\end{abstract}

Keywords: High Quality and Healthy Lake; Lake Zhelin; algae succession; cyanobacteria bloom; ecological security; drinking water safety

我国湖泊水体富营养化问题较突出, 典型代表是“三湖” (太湖、巢湖和滇池) 的富营养化和蓝藻水华问

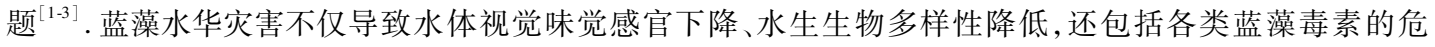

* 国家良好湖泊生态环境保护专项、江西环保科技项目 (JXHBKJ201214)、江西水利科技项目 ( KT201307) 和国家自 然科学基金项目(31000179) 联合资助. 2014-05-06 收稿;2014-07-02 收修改稿. 戴国飞(1985 ), 男，博士; E-mail: daiguofei1985@126.com. 
害 $^{[4-5]}$. 尽管近年来中央和地方政府投人了大量财力物力治理, 但目前为止效果仍不够显著. 为保护湖泊生 态环境,改善水质,避免走“先污染、后治理” 的老路,2011 年来,国家环境保护部和财政部正大力推进水质 较好湖泊生态环境保护, 江西省九江市柘林湖作为首批人围国家良好湖泊保护专项示范的湖泊, 其富营养 化现状与藻类季节区域分布特征研究对全国其他湖泊保护具有参考意义.

目前关于蓝藻水华形成的机理已有较多的研究,一般认为蓝藻水华的形成是由蓝藻自身的生理特点及 环境中温度、光照、营养盐等诸多因素所引发的 ${ }^{[6]}$. 有关实验表明部分蓝藻的最佳生长温度高于其它藻类, 比如太湖微囊藻的最适生长温度为 $30 \sim 35^{\circ} \mathrm{C}$, 因此夏、秋季节的高温天气易引发湖泊蓝藻水华发生 ${ }^{[7]}$. 此外 蓝藻仅需较少的能量就能维持细胞代谢, 因此在较低的光照条件下 (如水体浑浊透明度较低和风浪扰动作 用下) 蓝藻可以比其它藻类具有更高的生长速率和更强的竞争优势 ${ }^{[8]}$. 研究表明蓝藻具有较高的磷吸收摄 取及存储能力, 对磷、氮等营养盐的结合力比其它藻类强, 在氮、磷浓度较低的环境中, 具有比其它藻类更强 的竞争力 ${ }^{[9]}$. 因此,在许多氮、磷浓度较低的水质良好湖泊中, 也时常可以见到蓝藻水华现象. 此外,水文、气 候、气象等因素也可以通过影响湖泊水体的分层、混合等,直接或间接地影响蓝藻的生长和暴发,如夏、秋高 温季节深水湖泊水体易发生分层, 底部的水处于缺氧状态从而使得底泥处于还原性环境中, 底泥磷易在缺 氧还原性条件下不断释放扩散到上层水体供藻类生长吸收利用, 从而造成藻类大量生长 ${ }^{[10]}$.

柘林湖水资源丰富, 湖区多个大型饮用水源地供应着九江市和周边县市居民饮水. 同时环湖区县市的 农业、工业及服务业发展也均依赖柘林湖, 因此湖区的生态安全对周边居民健康和经济健康发展均具有至 关重要的意义. 目前湖区居民的人为活动已对柘林湖水质和生态环境造成了一定影响, 为了探明柘林湖水 质和生态环境状况, 本研究初步分析了柘林湖水体营养盐和富营养化状况以及湖区藻类演替规律, 并对主 要人湖支流和重要饮用水源地进行了藻类现状调查, 以期为进一步研究和提出柘林湖良好湖泊保护措施建 议提供科学依据.

\section{1 材料与方法}

\section{1 研究对象}

柘林湖通过人工拦截鄱阳湖五大支流之一 “修河” 形成, 是江西省最大的人工湖. 柘林湖流域内有大小 支流 603 条, 坝址以上汇水区域面积 $9340 \mathrm{~km}^{2}$, 湖区水域面积 $308 \mathrm{~km}^{2}$, 总容量为 $79.2 \times 10^{8} \mathrm{~m}^{3[11]}$. 本研究调 查的湖区大部分水深在 $15 \sim 25 \mathrm{~m}$ 之间, 下游坝区水深达 $45 \mathrm{~m}$. 湖区夏、秋季节水体分层较为明显, 表层水温 $26 \sim 33^{\circ} \mathrm{C}$, 中下层水温 $18 \sim 25^{\circ} \mathrm{C}$, 温跃层距表层水约 $9 \sim 12 \mathrm{~m}$.

\section{2 研究方法}

本研究在湖区设置 16 个采样点 (图 1), 同时采集 4 条主要人湖河流点, 采样时间从 2012 年 8 月到 2013

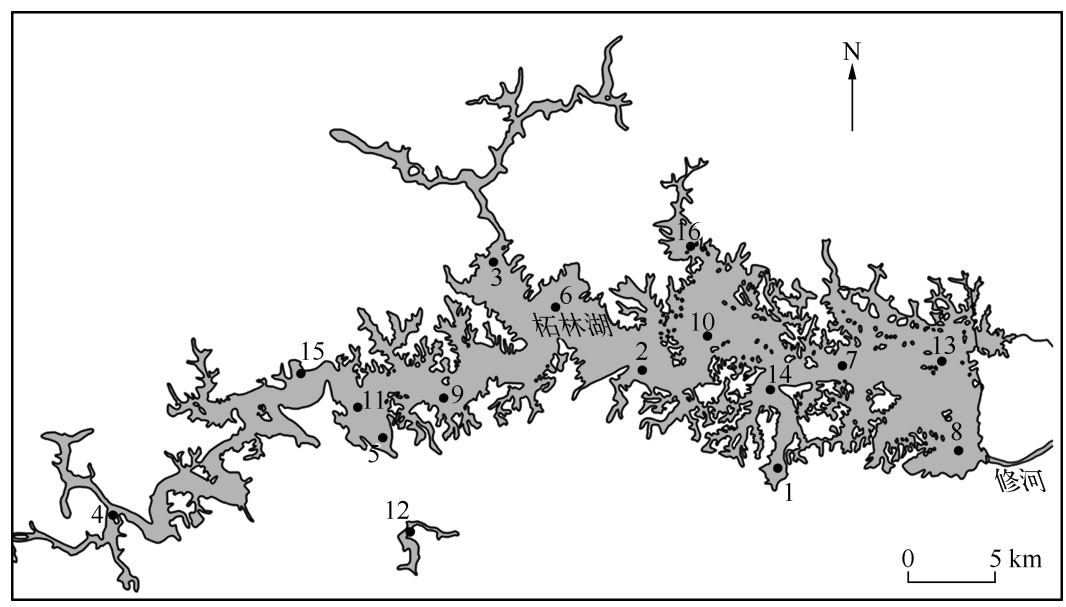

图 1 柘林湖湖区采样点分布

Fig. 1 Sampling sites in Lake Zhelin in the study 
年 7 月, 湖北部由 $3^{\#} 、 6^{\#} 、 16^{\#}$ 点位代表, 湖中部由 $7^{\#} 、 9^{\#} 、 10^{\#}$ 点位代表, 湖南部由 $1^{\#} 、 2^{\#} 、 14^{\#}$ 代表, 湖东部由 $8^{\# 、}$ $13^{\#}$ 代表, 湖西部由 $4^{\#} 、 5^{\#} 、 11^{\#} 、 15^{\#}$ 代表. 采集表层水 $(0 \sim 0.5 \mathrm{~m})$ 与底层水 (距底部 $\left.0 \sim 0.5 \mathrm{~m}\right)$ 混合水样. 采样 现场测定水温和透明度, 同时取 $1 \mathrm{~L}$ 水样用鲁哥试剂 (浓度约 $1.5 \%$ ) 固定用于浮游植物定量测定. 各类水质 指标包括叶绿素 $\mathrm{a} 、$ 硝态氮、氨氮、高锰酸盐指数和总溶解性磷等均采用国标法测定. 部分蓝藻较多区域还对 溶解性微囊藻毒素进行了测定, 原水用 $0.45 \mu \mathrm{m}$ 滤膜过滤后 $-20^{\circ} \mathrm{C}$ 保存, $72 \mathrm{~h}$ 内用 ELISA 法直接测定, 该方 法具体操作步骤参考以往文献报道 ${ }^{[12-13]}$.

浮游植物计数采用血球计数板法, 鉴定方法参考《中国淡水藻类——系统、分类及生态》 ${ }^{[14]}$ 和《淡水微 型生物图谱 $\rangle^{[15]}$. 优势种由 Mcnaughton 指数 $Y$ 确定, $Y=\left(n_{i} / N\right) f_{i}, n_{i}$ 为为第 $i$ 种藻类的细胞数, $N$ 为样品中所 有藻类的总细胞数, $f_{i}$ 为第 $i$ 种藻类在各样点出现的频率, 将优势度指数 $Y>0.02$ 的藻类定为优势种 ${ }^{[16]}$.

\section{2 结果与分析}

\section{1 柘林湖水体营养盐及富营养化现状}

综合柘林湖全年水质结果可以看到,柘 林湖总磷全年平均在 $0.03 \mathrm{mg} / \mathrm{L}$ 左右, 总氮 平均在 $0.65 \mathrm{mg} / \mathrm{L}$ 左右 (图 2), 湖体水质总 磷、总氮全年维持在 III 类水以下. 综合叶绿 素和高锰酸盐指数等水质参数计算得到柘 林湖水体富营养化指数, 发现其在 $30 \sim 35$ 范围内变动 (图 2), 湖泊水体处于中营养状 态, 水质总体较健康, 符合良好湖泊的基本 要求. 但在 8-11 月份, 湖区的总磷和总氮 均有逐月上升的趋势. 受湖周边人口分布及 人工湖自身形态构造影响, 柘林湖湖区营养 盐分布较不均匀, 其西区 (水库上游) 人口密 集区水体营养盐浓度明显高于柘林湖东区 (水库下游), 如西区的武宁周边区域总氮、 总磷平均值分别约为 $0.78 、 0.036 \mathrm{mg} / \mathrm{L}$, 东 区坝上区域总氮、总磷平均值约为 0.62 、 $0.026 \mathrm{mg} / \mathrm{L}$. 同时西区为修河水进人柘林湖 的减速过渡区域,河流营养盐沉降也对西区 营养盐分布有较大影响, 如位于修河一柘林 湖过渡区域的一个饮用水源地,其总氮水平 $4-8$ 月均维持在 $0.79 \sim 0.97 \mathrm{mg} / \mathrm{L}$, 高于同 期其它大部分点位.

\section{2 柘林湖藻类季节与空间分布}

从图 3 可以看出, 柘林湖藻类季节性演 替以蓝藻和硅藻交替为主, 夏季柘林湖蓝藻 占绝对优势, 优势种主要为鱼腥藻和微囊 藻; 秋季柘林湖硅藻与蓝藻同时占优势, 优 势种主要为直链藻、小环藻和鱼腥藻; 冬季 硅藻占优势, 到春季又恢复到蓝藻和硅藻共 同占优势, 具体优势种藻类变化见表 1 . 根 据浮游植物采样点的空间分布归类, 将湖区 16 个采样点分别纳人各个湖区方位进行季

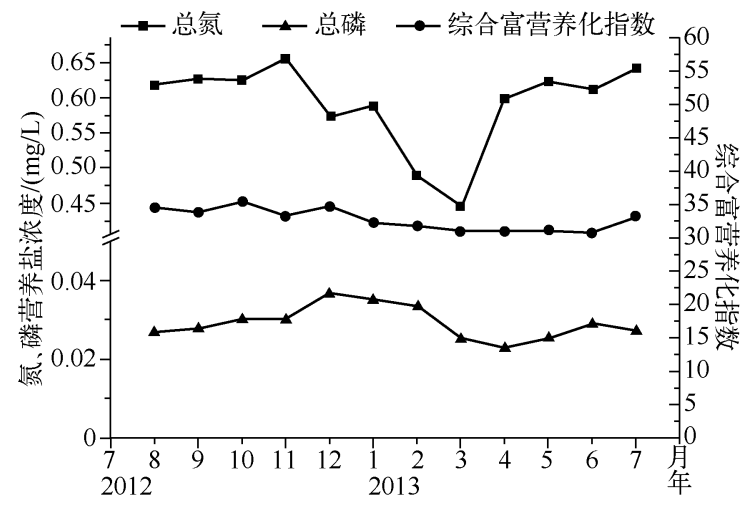

图 22012 年 8 月一-2013 年 7 月柘林湖水体总磷、总氮 和综合富营养化指数变化

Fig. 2 Variations of total phosphorus, total nitrogen and comprehensive index of eutrophication of Lake Zhelin from August, 2012 to July, 2013

表 1 柘林湖不同季节的藻类优势种 *

Tab. 1 The dominant species of algae in Lake Zhelin in different seasons

\begin{tabular}{lcccc}
\hline 优势种 & 夏季 & 秋季 冬季 春季 \\
\hline 类颤藻鱼腥藻 Anabaena oscillarioides & $*$ & $*$ & $*$ & $*$ \\
水华鱼腥藻 Anabaena flos-aquae & $*$ & $*$ & & $*$ \\
挪氏微囊藻 Microcystis novacekii & $*$ & $*$ & & \\
鱼害微囊藻 Microcystis ichthyoblabe & $*$ & & & \\
颗粒直链藻 Melosira granulate & & $*$ & $*$ & $*$ \\
变异直连藻 Melosira varians & & $*$ & $*$ & $*$ \\
梅尼小环藻 Cyclotella meneghiniana & & $*$ & $*$ & $*$ \\
细粒囊裸藻 Trachelomonas granulosa & & & $*$ & \\
针脆杆藻 Fragilaria capucina & $*$ & & $*$ & \\
尖针杆藻 Synedra acus & $*$ & $*$ & & $*$ \\
卵形隐藻 Cryptomonas ovata & & & $*$ & $*$ \\
普通肋缝藻 Frustulia vulgaris & $*$ & & $*$ & \\
新月桥湾藻 Cymbella cymbiformis & & & $*$ & \\
四尾柵藻 Scenedesmus quadricauda & & $*$ & $*$ & $*$ \\
纤细角星鼓藻 Staurastrum gracile & $*$ & & & \\
\hline
\end{tabular}

* 表示在此季节为优势种. 
节性丰度分析. 由图 4 可以看出, 全湖浮游植物丰度夏季最高; 秋、冬季随着气温的不断下降及光照的逐渐 减弱, 浮游植物丰度持续减少; 春季随着气温的逐渐回升, 有利的条件促使浮游植物重新快速增长. 从柘林 湖空间分布情况来看, 夏季柘林湖西部湖区浮游植物生物量和丰度最高, 面临的湖泊生态保护压力最大, 其 次是湖区东部和中部. 秋季以后柘林湖东部浮游植物丰度相对较高, 柘林湖为修河经人工拦截形成的人工 水库, 因此同时具有河流型水库的特性, 取柘林湖上、中、下游各个代表性点位作比较, 同样可以得到类似的 湖区浮游植物空间分布规律. 柘林湖浮游植物超标主要发生在水库上游区域 (上游的所有点位均发生了不 同程度的轻微蓝藻水华), 水库中游和下游区域总体生态安全性较高. 上游主要为生活和工业性人工干扰, 经过中游和下游的水库涵养净化, 水体生态安全性得到了一定的改善提高; 浮游植物丰度为: 上游 > 中游 > 下游, 符合传统水库型湖泊的典型分布特征 ${ }^{[10]}$.

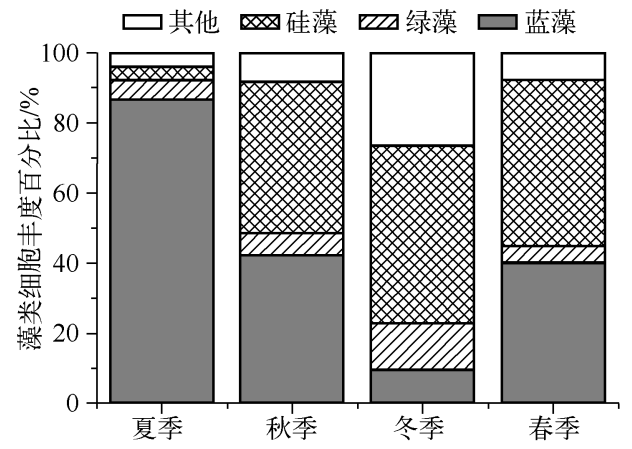

图 3 柘林湖藻类细胞丰度百分比的季节变化

Fig. 3 Abundance percentage of different algae cells in Lake Zhelin in different seasons

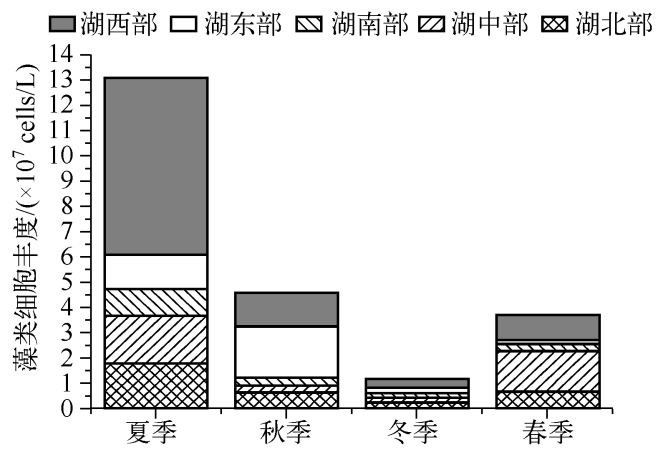

图 4 柘林湖不同位区域浮游植物季节分布规律

Fig. 4 Spatial distribution of algae in different areas of Lake Zhelin

\section{3 柘林湖各饮用水源地浮游植物丰度分布}

柘林湖及周边共有 3 个饮用水源地, 分别为东渡水源地、源口水库、附三坝水源地. 如图 5 所示, 夏季 3 个饮用水源地藻类优势种群均为蓝藻, 主要有鱼腥藻和微囊藻, 其中鱼腥藻丰度占藻类细胞总丰度 $80 \%$ 以 上, 东渡水源地浮游植物丰度为 $9.96 \times 10^{7} \mathrm{cells} / \mathrm{L}$, 已经达到了较重的水华程度. 秋季东渡水源地和附三坝 水源地浮游植物均已轻微超标, 但东渡水源地的优势种群依然为蓝藻, 其次是硅藻, 而附三坝水源地的优势 种主要为硅藻 (直链藻), 其次为蓝藻. 春季源口水库的藻类以硅藻占绝对优势, 虽然生物量偏大, 但硅藻的 种类多样性高, 单一种类的硅藻水华风险仍较低. 东渡水源地尽管浮游植物的生物量并不高, 但是蓝藻所占 的比例已经逐步接近优势种, 表明随着春季气温升高此水源地蓝藻生物量可能快速回升.

\section{4 柘林湖 4 条主要入湖支流浮游植物丰度分布}

柘林湖 4 条主要人湖支流为瓜源水、罗坪水、巾口水、烟港水. 选具典型代表意义的夏季和冬季分析各 人湖口支流浮游植物丰度情况 (图 6), 夏季 4 条人湖口河流的浮游植物丰度排列顺序为: 烟港水 $>$ 巾口水 $>$ 罗坪水 $>$ 瓜源水, 各人湖口河流水流速度均较慢, 藻类均以硅藻和蓝藻占优势. 瓜源水生态安全性最高, 为 将来作为九江市饮用水源地打下了较好的安全基础. 冬季除烟港水浮游植物丰度依然较高外, 其他几条人 湖河流的浮游植物丰度均较低, 各支流藻类优势种均为硅藻. 烟港水全年的浮游植物丰度均较高, 主要原因 可能为烟港水区域拦河建坝较多, 水流速度急速下降, 水体封闭性大大加强, 营养盐来不及扩散就被浮游生 物吸收利用.

\section{3 讨论}

\section{1 柘林湖水位、水量变化对湖区蓝藻暴发的影响}

邬红娟等 ${ }^{[17]}$ 对黑龙滩水库的研究表明, 水库的低水位运行将对库内浮游生物的生物量提高提供有利条 件. 且水库浮游植物多样性也与水位呈正相关 ${ }^{[18]}$. 湖区降雨量是影响水位变化的一个关键因素, 针对太湖蓝 藻暴发规律的研究指出, 低降雨量 (表现为湖泊水文站测得的来水量) 也将加大湖泊蓝藻暴发风险 ${ }^{[19]}$. 柘林 
湖雨季来水量在 6 月份达到顶峰后, 随后的 7-10 月夏、秋高温季节呈急剧持续下降趋势 (图 7a). 受降雨和 水库调节运行影响, 柘林湖湖区在高温的 7-10 月水位均逐月下降 (图 7b), 相应的氮、磷营养盐浓度在此期 间呈逐月上升趋势 (图 2). 且柘林湖位于亚热带地区, 夏、秋季节持续的强太阳光照射为蓝藻生长提供了优 良的条件.上述因素对湖区蓝藻增殖和局部湖区的蓝藻水华暴发均会产生积极影响.

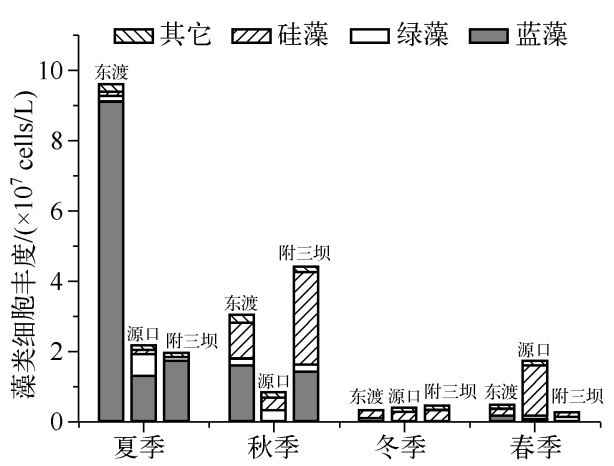

图 5 柘林湖区 3 大水源地 (东渡、源口 和附三坝) 各季节藻类丰度与组成

Fig. 5 Algae cells abundance and composition of the three drinking water sources

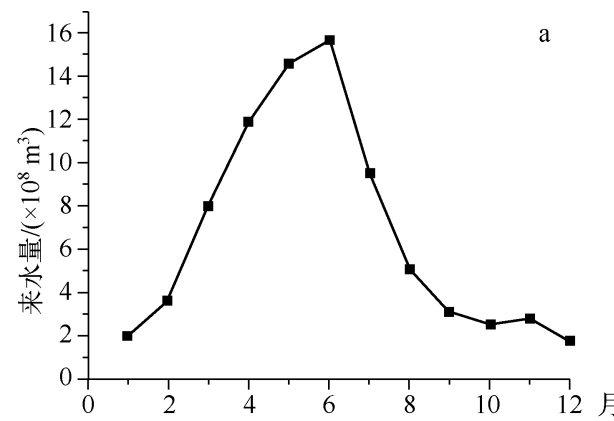

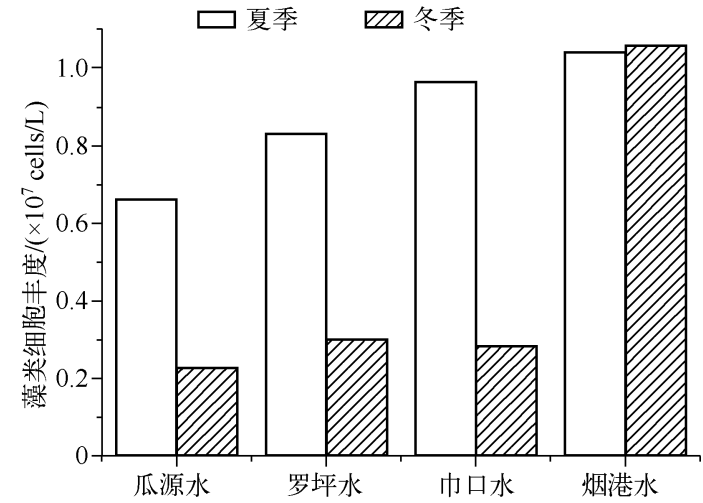

图 6 夏、冬季节柘林湖人湖河流的浮游植物丰度分布

Fig. 6 The algae cell abundance in four main rivers into Lake Zhelin in summer and autumn

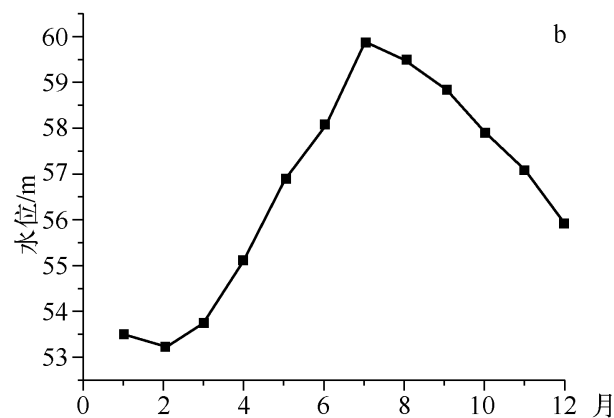

图 7 柘林湖全年来水量 (a) 和水位 (b) 月变化

Fig. 7 The monthly variations of input water volume(a) and water level(b) of Lake Zhelin

\section{2 柘林湖形态构造和局部水文特性对蓝藻时空分布的影响}

3.2 .1 河一湖缓冲过渡带的影响从柘林湖蓝藻分布可以看出, 湖区高丰度蓝藻主要分布在柘林湖西区, 这 可能与柘林湖水文形态构造导致的营养盐分布不均有关. 柘林湖 (水库) 是人工拦截鄱阳湖五大支流之一的 “修河”而成. 湖区西部武宁县区域为修河与柘林湖的“河流-湖泊过渡带” 区域, 水中夹带着大量藻类生长必 需的氮、磷等营养盐, 且流速较高的修河河水在到达柘林湖西部武宁县空间开阔的大湖面后流速急剧下降, 水体污染物在过渡带区域沉降蓄积, 为浮游生物生长提供了优良生境. 监测结果表明,柘林湖西部上游过渡 带水体营养盐浓度比湖区东部坝区平均高 $30 \%$ 左右,为蓝藻在该区域的大量生长提供了必要的物质条件, 该河流型水库污染物分布特征与 Kalff 的湖沼学研究结果较为符合 ${ }^{[10]}$. 柘林湖 3 大饮用水源地之一的东渡 水源地正好位于该河流-湖泊过渡带中心,其营养盐水平较同期柘林湖其它区域点位高,因此夏、秋季节蓝 藻水华频繁发生,最高丰度达到 $9.96 \times 10^{7} \mathrm{cells} / \mathrm{L}$. 在污染负荷和蓝藻水华日趋严重的形势下,为保障供水 安全,建议取消该方位的饮用水源地,将取水地移到柘林湖中东部区域.

3.2 .2 水体分层与透明度的影响 柘林湖大部分湖区水深在 $15 \sim 25 \mathrm{~m}$ 之间, 下游坝区水深可达 $45 \mathrm{~m}$, 夏、秋 季节水体分层较为明显, 表层水温 $26 \sim 33^{\circ} \mathrm{C}$, 中下层水温 $18 \sim 25^{\circ} \mathrm{C}$, 温跃层距表层水约 $9 \sim 12 \mathrm{~m}$, 水体混合 
层较深, 有利于适应低光的藻类如鱼腥藻形成优势. 受河流悬浮物影响, 西部过渡带区域水体透明度大多只 有 $1 \mathrm{~m}$ 左右, 夏季水面强光照射在一定程度上得到了遮蔽. 段紫星 ${ }^{[20]}$ 对水华鱼腥藻生长的研究表明, 低光照 $(1000 \mathrm{~lx})$ 和较高的水温 $\left(30^{\circ} \mathrm{C}\right)$ 将有利于鱼腥藻的大量快速增殖, 这也是柘林湖西部湖区蓝藻水华以水华鱼 腥藻和类颤藻鱼腥藻为主要优势种的原因之一. 此外, 郭跃华等在研究广东高州水库时指出, 在枯水期水库 流量较小, 水体冲刷率较低, 水体稳定性高, 在此条件下丝状蓝藻如水华鱼腥藻易成为蓝藻优势种, 从而形 成水华 ${ }^{[21]}$. 柘林湖枯水期湖区来水量小, 西部湖面开阔水体几乎呈静止稳定状态, 同时湖区沉淀的营养物质 丰富, 为蓝藻增殖和水华暴发提供了优良的外部条件.

3.2 .3 水体滞留时间的影响 湖泊水体滞留时间是衡量湖泊水体稳定性的另一个重要指标, 反映了湖泊水 体受外界干扰的程度. 大量研究表明, 水体滞留时间越长, 湖泊水体越稳定, 受外界干扰越小, 湖水中的浮游 植物生物量特别是蓝藻丰度就越高 ${ }^{[22-23]}$. Straskraba 等和 Han 等对大部分分层湖泊的研究表明, 其湖泊水体 滞留时间平均约为 $100 \mathrm{~d}^{[24-25]}$. 而柘林湖的换水周期平均为 $430 \mathrm{~d}$, 远远超过分层湖泊的平均换水周期. 加上 近年来柘林湖湖区大力发展网箱养殖, 部分湖湾和浅水区域水体营养盐超标较多, 水体滞留时间长, 水体交 换速度慢, 造成部分湖区营养盐历史蓄积较多, 引起这些湖区常年定期暴发藻华, 如柘林湖部分湖湾因过去 大面积水产养殖, 虽近几年已经被取缔, 但这些地区夏季仍然频繁发生蓝藻水华, 冬季硅藻又过量生长繁 殖. 因此为了防止藻类水华的发生, 除了削减人湖营养盐, 开展必要的生态修复外, 还需对柘林湖进行适当 的湖泊管理如人工泄流换水,加速湖泊水体更新.

\section{3 柘林湖湖区饮用水安全风险}

柘林湖东渡水源地蓝藻水华优势种为鱼腥藻, 包括水华鱼腥藻和类颤藻鱼腥藻, 此外还夹杂着部分群 体微囊藻. 这些藻类 (蓝藻) 在湖区其它点位也均有发现, 并已成为夏、秋季节湖区的优势种群. 据已有文献 报道, 在 2006-2007 年柘林湖仍以腔球藻 (Coelosphaerium)、微囊藻、飞燕角甲藻 (Ceratium hirundinell)、角星 鼓藻 (Staurastrum) 为主要优势种群, 相比可见, 柘林湖局部湖区水生态安全有逐步退化的迹象 ${ }^{[26]}$. 鱼腥藻产 毒种类较多, 文献报道的主要有微囊藻毒素、鱼腥藻毒素-a(Anatoxin-a)、鱼腥藻毒素-a(s) (Anatoxin-a (s))、 石房蛤毒素 ( saxitoxin)、拟柱胞藻毒素 ( cylindrospermopsin) 等 ${ }^{[27]}$. 微囊藻毒素是一种单环七肽化合物, 对人 体和动物有致癌致畸风险, 自太湖蓝藻暴发事件以来已成为公众关注较多、研究较深人的蓝藻毒素种 类 ${ }^{[28-29]} .2012$ 年 8 月- 2013 年 7 月的监测数据表明, 尽管柘林湖水源地蓝藻数目较高, 但微囊藻毒素含量很 低, 最高含量 ( $8 、 9$ 月份) 也不超过 $0.2 \mu \mathrm{g} / \mathrm{L}$, 大部分时间检测不到 $(<0.1 \mu \mathrm{g} / \mathrm{L}$ ), 因此与太湖、滇池等地的蓝 藻水华研究结果相比, 其相对风险可能较低 ${ }^{[30-31]}$. 但在水质异味影响上与太湖蓝藻水华造成的结果类似, 夏、秋季节附近居民均能从自来水中明显感觉到水体挥发出的土腥味 (由于监测条件限制, 未能完成水源地 异味物质的具体鉴定检测). 现场调研发现该嗅觉异味与太湖饮用水事故中的味道较为相似 ${ }^{[32]}$, 相关政府 部门应当对此加以重视并采取切实有效的措施,保障湖区周边居民的饮用水安全.

\section{4 参考文献}

[ 1 ] Liu YM, Chen W, Li DH et al. Cyanobacteria-/cyanotoxin-contaminations and eutrophication status before Wuxi Drinking Water Crisis in Lake Taihu, China. Journal of Environmental Sciences-China, 2011, 23 : 575-581.

[2] 李大命, 孔繁翔, 张 民等. 太湖和巢湖夏季蓝藻水华期间产毒微囊藻和非产毒微囊藻种群丰度的空间分布. 应用 与环境生物学报, 2011,17(4):480-485.

[ 3 ] Sheng H, Liu H, Wang C et al. Analysis of cyanobacteria bloom in the Waihai part of Dianchi Lake, China. Ecological Informatics, $2012, \mathbf{1 0}: 37-48$.

[ 4 ] Pearson L, Mihali T, Moffitt M et al. On the chemistry, toxicology and genetics of the cyanobacterial toxins, microcystin, nodularin, saxitoxin and cylindrospermopsin. Marine Drugs, 2010, 8(5) : 1650-1680.

[ 5 ] Li Y, Chen JA, Zhao Q et al. A cross-sectional investigation of chronic exposure to microcystin in relationship to childhood liver damage in the Three Gorges Reservoir Region, China. Environmental Health Perspectives, 2011, 119: $1483-1488$.

[6] 孔繁翔,高 光. 大型浅水富营养化湖泊中蓝藻水华形成机理的思考. 生态学报,2005,25(3):589-595.

[ 7 ] 陈宇炜, 高锡云, 蔡启铭. 西太湖北部微囊藻时空分布及其与光温等环境因子关系的研究. 见: 蔡启铭编. 太湖环境 生态研究 (一). 北京:气象出版社,1998:142-148. 
[ 8 ] Oliver RL, Ganf GG. Freshwater blooms. In: Whitton BA, Potts M eds. The ecology of cyanobacteria. Dordrecht: Kluwer Academic Publishers, 2000 : 149-194.

[ 9 ] Fujimoto N, Sudo R. Nutrient-limited growth of Microcystis aeruignosa and Phormidium tenue and competition under various N:P supply ratios and temperatures. Limnology and Oceanography, 1997, 42 : 250-256.

[10] Kalff J. Limnology: inland water ecosystems. New Jersey: Prentice Hall, 2002.

[11] 刘慧丽,廖 兵. 柘林湖湖泊生态环境问题及保护对策. 江西科学, 2013,(1):48-52.

[12] Lei LM, Wu YS, Gan NQ et al. An ELISA-like time-resolved fluorescence immunoassay for microcystin detection. Clinica Chimica Acta, 2004, 348: 177-180.

[13] 雷腊梅, 甘南琴, 张小明等. 三种检测微囊藻毒素的 ELISA 方法比较研究. 高技术通讯,2004,14(7):89-92.

[14] 周凤霞,陈剑虹. 淡水微型生物图谱. 北京: 北京工业出版社,2010.

[15] 胡鸿钧,魏印心. 中国淡水藻类:系统分类及生态. 北京:科学出版社,2006.

[16] Menaughton SJ. Relationship among functional prosperities of California grassland. Nature, 1967, 216: $168-169$.

[17] 邬红娟,胡传林. 黑龙滩水库夏季不同水位对鱼产量和浮游生物群落结构的影响. 水生生物学报, 1995,19(4): $360-367$.

[18] 林秋奇, 胡 韧, 韩博平. 流溪河水库水动力学对营养盐和浮游植物分布的影响. 生态学报, 2003, 23 (11): 2278-2283.

[19］任 健,商兆堂,蒋名淑等.2007 年太湖蓝藻暴发的气象条件分析. 安徽农业科学,2008,36(27):11874-11877.

[20] 段紫星. 水华鱼腥藻过度繁殖机制及几种化学物质对其毒性效应研究 [学位论文]. 福州: 福建师范大学,2009.

[21] 郭跃华,陈修康, 张建林等. 广东省高州水库水华过程中蓝藻群落的动态特征. 湖泊科学,2011,23(4):527-533.

[22] 赵孟蓄,韩博平. 汤溪水库蓝藻水华发生的影响因子分析. 生态学报,2005,25(7):1554-1561.

[23] 胡 韧, 熊江霞, 韩博平. 具有短水力滞留的小型富营养化水库浮游植物群落结构与动态. 生态环境, 2008, 17 (4): 1319-1326.

[24] Straskraba M, Tundisi JG, Ducan A. State-of-the-art of reservoir limnology and water quality management. Comparative reservoir limnology and water quality management. Dordrecht: Kluwer Academic Publishers, 1993 : 213-288.

[25] Han BP, Armengol J, Garcia JC et al. The thermal structure of Sau Reservoir( NE: Span ) : a simulation approach. Ecological Modelling, 2000, $125: 109-122$.

[26] 肖秀兰,杨 春, 李 达等. 柘林湖浮游生物初步调查. 江西水产科技, 2008,3:22-24.

[27] Rapala J, Sivonen K. Assessment of environmental conditions that favor hepatotoxic and neurotoxic Anabaena spp. strains cultured under light limitation at different temperatures. Microbial Ecology, 1998, 36(2) : 181-192.

[28] Gan NQ, Sun XY, Song LR. Activation of Nrf2 by microcystin-LR provides advantages for liver cancer cell growth. Chemical Research in Toxicology, 2010, 23:1477-1484.

[29] Chen W, Song LR, Peng L et al. Reduction in microcystin concentrations in large and shallow lakes: water and sedimentinterface contributions. Water Research, 2008, 42: 763-773.

[30] 潘晓洁, 常锋毅, 沈银武等. 滇池水体中微囊藻毒素含量变化与环境因子的相关性研究. 湖泊科学, 2006,18 (6): $572-578$.

[31] Song LR, Chen W, Peng L et al. Distribution and bioaccumulation of microcystins in water columns: A systematic investigation into the environmental fate and the risks associated with microcystins in Meiliang Bay, Lake Taihu. Water Research, 2007, 41 : 2853-2864.

[32] Chen J, Xie P, Ma Z et al. A systematic study on spatial and seasonal patterns of eight taste and odor compounds with relation to various biotic and abiotic parameters in Gonghu Bay of Lake Taihu, China. Science of the Total Environment, 2010 , 409: 314-325. 